\title{
MOLECULAR ASPECTS OF CELLULAR REGULATION
}

\author{
VOLUME 6
}

General Editor

\section{PHILIP COHEN}

Dundee

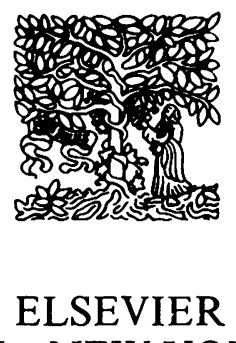

AMSTERDAM - NEW YORK - OXFORD 


\title{
THE HORMONAL CONTROL OF GENE TRANSCRIPTION
}

\author{
Edited by \\ PHILIP COHEN \\ and \\ J. GORDON FOULKES
}

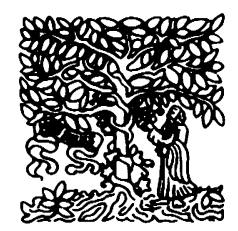

1991

ELSEVIER

AMSTERDAM - NEW YORK - OXFORD 


\section{Contents}

Editor's foreword

List of contributors vii

Contents $\quad$ xiii

Section I. Introduction $\quad 1$

Chapter 1. An overview of transcription, by N. Heintz and C. Desplan 3

1. Introduction 3

2. Anatomy of the transcription unit 3

2.1. The eukaryotic promoter 4

2.2. The enhancer 7

3. The structure and function of RNA polymerase II $\quad 8$

4. RNA polymerase II transcription initiation 11

$\begin{array}{ll}\text { 4.1. In vitro transcription } & 12\end{array}$

4.2. TFIID 12

4.3. TFIIA 14

4.4. TFIIB 14

$\begin{array}{ll}\text { 4.5. TFIIE } & 14\end{array}$

4.6. TFIIF-RAP30/74 14

4.7. SII 15

4.8. Formation of the RNA polymerase II initiation complex 15

4.9. Template committed complex 16

4.10. Pre-initiation complex 16

4.11. Activated initiation complex 17

$\begin{array}{ll}\text { 4.12. Elongation complex } & 17\end{array}$

4.13. Regulation of the formation of the initiation complex 17

4.14. Action of general transcription factors on TFIID 18

4.15. Inhibition of transcription by specific factors $\quad 19$

4.16. Release of elongation pauses 19

5. Transcription termination by RNA polymerase II 19

6. Concluding remarks 21 
xiv

References

Chapter 2. Regulation of eukaryotic RNA polymerase II transcription by sequence-specific DNA-binding proteins, by W. Herr

1. Introduction

2. Bipartite and universal activation $\quad 26$

3. Activators as developmental regulators $\quad 27$

4. The different modules for DNA binding and activation $\quad 28$

$\begin{array}{lr}\text { 4.1. DNA-binding domains } & 28\end{array}$

4.2. The HTH motif $\quad 30$

4.3. Zinc fingers $\quad 31$

4.4. Leucine zipper and HLH motifs $\quad 34$

4.5. Independent DNA-binding domains within a single protein 36

4.6. Flexible sequence recognition by eukaryotic DNA-binding proteins 37

4.7. Activation domains $\quad 37$

4.8. DNA-binding domains as activating regions 39

5. Enhancer organization: the SV40 enhancer 41

6. Levels of synergism between enhancer-bound transcription factors 45

7. Mechanism of enhancer function 46

8. Differential transcriptional activation by Oct-1 and Oct-2: two proteins that bind to the same DNA sequence $\quad 46$

8.1. Differential positive and negative regulation of transcription by the Oct factors 48

8.2. The C-termini of Oct- 1 and Oct-2 specify different transcriptional activation potentials 49

8.3. Oct-2 phosphorylation correlates with transcriptional activation potential 50

$\begin{array}{lr}\text { 9. Conclusions and perspectives } & 51\end{array}$

$\begin{array}{lr}\text { Acknowledgements } & 52\end{array}$

$\begin{array}{lr}\text { References } & 52\end{array}$

Chapter 3. Hormonal effects on gene suppression mediated through transacting factors and chromatin structure, by I.H. Williams and J.D. Haley

1. Introduction

2. Chromatin structure and suppression of transcription 58

2.1. Phased nucleosomes 58

2.2. DNase I-sensitive sites $\quad 59$

$\begin{array}{ll}\text { 2.3. Nucleoskeleton } & 60\end{array}$

2.4. DNA methylation 61

2.5. Transcriptional interference 61

3. Gene suppression mediated by trans-acting factors 62

3.1. Gene extinction 62

3.2. Suppression of three different classes of genes $\quad 64$

3.3. Role of suppression in class 1 gene transcription 65 
3.4. Suppressors modulate transcription of class 2 genes 65

3.5. The role of suppression in class 3 gene transcription $\quad 66$

4. Suppression of gene transcription by steroid hormone receptors 68

5. Viral factors may mimic host cell suppressors $\quad 69$

6. Gene suppression by transcriptional termination and blocked RNA elongation 70

$\begin{array}{ll}7 . & \text { Conclusions } \\ \end{array}$

$\begin{array}{lr}\text { References } & 72\end{array}$

Chapter 4. An overview of signal transduction, by P.J. Parker 77

$\begin{array}{ll}\text { 1. Introduction } & 77\end{array}$

2. Cell surface receptors $\quad 79$

2.1. G protein-linked receptors $\quad 79$

2.2. Receptors with catalytic functions $\quad 80$

$\begin{array}{ll}\text { 2.2.1. Protein-tyrosine kinase receptors } & 81\end{array}$

\begin{tabular}{ll} 
2.2.2. & CD45 and LAR \\
\hline
\end{tabular}

$\begin{array}{ll}\text { 2.2.3. Guanylate cyclase receptors } & 84\end{array}$

$\begin{array}{lr}\text { 2.3. Ion channels } & 84\end{array}$

2.4. Receptor-protein interactions $\quad 85$

3. Second messenger generation $\quad 85$

3.1. Gs-adenylate cyclase $\quad 86$

3.2. Transducin-cGMP phosphodiesterase $\quad 87$

3.3. Inositol-specific phospholipase C $\quad 87$

3.4. Phospholipase $\mathrm{A}_{2} \quad 89$

3.5. Other $G$ protein-linked signalling systems $\quad 89$

4. Second messenger receptors $\quad 90$

4.1. cAMP-dependent protein kinase $\quad 91$

4.2. cGMP receptors $\quad 91$

4.3. Protein kinase C $r$

4.4. $\mathrm{Ca}^{2+}$ calmodulin $r$

5. Non-linear signal transduction $\quad 94$

$\begin{array}{lr}\text { References } & 95\end{array}$

Section II. Regulation by hormone receptor-DNA-binding proteins: the steroid superfamily 99

Chapter 5. Mechanisms of regulation of gene transcription by steroid receptors, by M.-J. Tsai and B.W. O'Malley

1. Introduction 101

2. Structure of the steroid receptor 101

3. A model for steroid hormone regulation of target genes 104

4. Conversion of steroid receptors from the 8-10S complex to the 4-5S complex 105

$\begin{array}{ll}\text { 5. Receptor-DNA interactions } & 106\end{array}$ 
6. Role of steroid hormone receptor in the induction of target gene transcription 108

7. The role of hormone in receptor function 110

8. Synergistic interaction of steroid response elements 111

9. Conclusions and perspective 113

$\begin{array}{ll}\text { References } & 113\end{array}$

Chapter 6. Regulation of transcription by glucocorticoids, by M. Beato, U. Brüggemeier, G. Chalepakis, R.J.G. Haché, M. Kalff, B. Piña, E. Slater and $M$. Truss

$\begin{array}{lll}\text { 1. Introduction } & 117\end{array}$

2. Positive regulation of transcription: the mouse mammary tumor virus (MMTV) promoter 118

2.1. Binding of the glucocorticoid receptor to the MMTV promoter 119

2.2. Role of DNA topology on hormone inducibility and receptor binding to DNA $\quad 120$

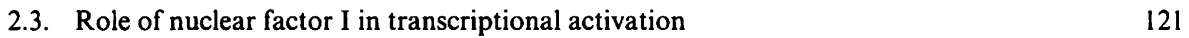

$\begin{array}{ll}\text { 2.4. Role of chromatin structure in MMTV transcription } & 122\end{array}$

3. Negative regulation of transcription by glucocorticoid hormones 124

$\begin{array}{ll}\text { 4. Conclusions } & 125\end{array}$

$\begin{array}{ll}\text { Acknowledgements } & 126\end{array}$

$\begin{array}{ll}\text { References } & 126\end{array}$

Chapter 7. Regulation of gene transcription by thyroid hormones and retinoic acid, by C.K. Glass and M.G. Rosenfeld

1. Introduction

2. Regulation of gene transcription by thyroid hormones 131

2.1. Biochemical properties of thyroid hormone receptors 131

2.2. Specific interactions of thyroid hormone receptor with target genes 133

$\begin{array}{ll}\text { 2.3. Thyroid hormone receptor genes } & 138\end{array}$

$\begin{array}{ll}\text { 2.3.1. The c-erb A alpha gene } & 138\end{array}$

$\begin{array}{ll}\text { 2.3.2. The beta } T_{3} \text { receptor gene } & 140\end{array}$

2.4. Functional analysis of erb A gene products $\quad 142$

$\begin{array}{ll}\text { 2.4.1. DNA-binding properties of erb A gene products } & 142\end{array}$

2.4.2. Properties of the hormone-binding domain of c-erb A gene products 142

$\begin{array}{ll}\text { 2.4.3. Transcriptional properties of erb A gene products } & 143\end{array}$

$\begin{array}{ll}\text { 2.4.4. Post-transcriptional modifications of } T_{3} \text { receptors } & 145\end{array}$

3. Regulation of gene transcription by the retinoic acid receptor 145

$\begin{array}{ll}\text { 3.1. Biological actions of retinoids } & 145\end{array}$

$\begin{array}{ll}\text { 3.2. Cellular proteins that bind retinoids } & 146\end{array}$

$\begin{array}{ll}\text { 3.2.1. Identification of cDNAs encoding retinoic acid receptors } & 147\end{array}$

$\begin{array}{ll}\text { 3.3. Regulation of gene expression by retinoic acid } & 149\end{array}$

3.4. Retinoic acid receptor-DNA interactions $\quad 150$

3.5. Biochemical studies of the retinoic receptor 151

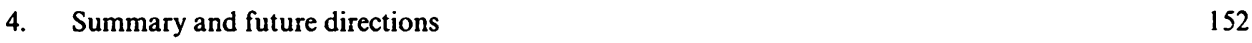


Section III. Regulation of transcription by second messenger systems

Chapter 8. Characteristics of the CAMP response unit, by M.R. Montminy, G.A. Gonzales and K.K. Yamamoto

Chapter 9. Probing cAMP-regulated gene expression with a recombinant protein kinase inhibitor, by J.R. Grove and J. Avruch

1. Introduction

2. Protein kinase inhibitor

2.1. Protein kinase inhibitor: structure-function relationships

2.2. Construction and expression of genes encoding PKI peptides

3. PKI (1-31) inhibits cAMP-stimulated gene expression specifically

4. $\mathrm{PKI}(1-31)$ does not inhibit protein kinase $\mathrm{C}$ activity in the intact cell

5. PKI(1-31) identifies the recruitment of PK-A regulated gene expression by other second messenger pathways

6. PK-A participates in the regulation of gene expression at basal levels of cAMP

7. Potential mechanisms involved in the tuning of cAMP-regulated gene expression

8. Conclusions

Acknowledgements

Chapter 10. Urokinase-type plasminogen activator gene regulation as a model system for studying transcriptional activation by the cAMP-dependent protein kinase pathway, by Y. Nagamine, M.S. Altus, J.-i. Nakagawa, D. Pearson and D. von der Ahe

1. Introduction

2. UPA expression in LLC-PK ${ }_{1}$ cells

2.1. uPA activity induced by cAMP in LLC-PK ${ }_{1}$ cells

2.1.1. Increase in UPA activity due to an increase in UPA mRNA concentration

2.1.2. The uPA gene as the primary target of calcitonin action

2.2. Analysis of the UPA gene promoter

2.2.2. Gene expression from stably integrated templates 
xviii

2.2.3. Protein-protein interaction in the cAMP-responsive region 209

2.2.4. A role of protein phosphorylation on DNA-protein interactions 210

$\begin{array}{ll}\text { 2.3. Negative regulation of uPA gene expression } & 212\end{array}$

2.3.1. Negative regulation at transcriptional and post-transcriptional levels 212

$\begin{array}{ll}\text { 2.4. Genetic approach } & 215\end{array}$

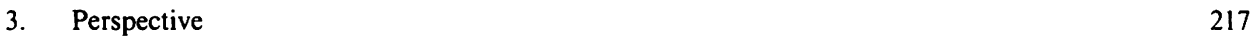

$\begin{array}{lr}\text { Acknowledgements } & 218\end{array}$

$\begin{array}{lr}\text { References } & 219\end{array}$

Chapter 11. Hormonal and liver-specific control of expression of the tyrosine aminotransferase gene, by D. Nitsch, S. Ruppert, G. Kelsey, A. Schedl, F. Wein, A.F. Stewart, U. Strähle, W. Schmid, C. de Vack, A. Reik, M. Boshart and G. Schütz

1. The tyrosine aminotransferase gene as a model system to study the interplay of controlling genes and hormone-signalling pathways

2. Two distinct trans-acting loci control overlapping sets of liver-specific genes

3. Alterations in chromatin structure indicate cis-acting regulatory sequences of the TAT gene

4. The glucocorticoid enhancer of the TAT gene

5. Cell-specific expression of the TAT gene

5.1. The -3.6 enhancer is composed of a cAMP-responsive sequence and a liver cell-specific element

5.2. Reversal of extinction by cAMP 232

6. Summary

References

Chapter 12. The AP-1 complex and its role in transcriptional control by protein kinase $C$, by $M$. Karin

1. Introduction

2. Jun-fos interactions

3. Transcriptional control of c-jun expression

4. Post-translational control of AP-1 activity

5. Negative regulation of $c$-jun expression

6. The role of AP-1 in cellular proliferation and differentiation 
Chapter 13. Genes induced by serum growth factors, by L.F. Lau and D. Nathans

1. Introduction

2. Detection of genes and proteins induced by serum growth factors

2.1. Detection of inducible proteins

2.2. Detection of induced mRNAs

3. Activation and expression of immediate early genes

3.1. Kinetics and patterns of mRNA changes

3.2. Transcriptional activation

3.3. Transcriptional repression

3.4. mRNA stability

3.5. Mechanisms of gene activation

$\begin{array}{ll}\text { 4. Proteins encoded by immediate early genes } & 267\end{array}$

4.1. Known or probable transcription factors 268

$\begin{array}{ll}\text { 4.1.1. Jun family members } & 268\end{array}$

$\begin{array}{ll}\text { 4.1.2. Fos family members } & 269\end{array}$

$\begin{array}{ll}\text { 4.1.3. Nuclear proteins containing zinc fingers } & 269\end{array}$

4.1.3.1. Zif268 (NGF-IA, erg-1, krox24) 270

$\begin{array}{ll}\text { 4.1.3.2. Krox } 20 & 270\end{array}$

$\begin{array}{ll}\text { 4.1.3.3. Nur77 (NGF-IB, N10) } & 270\end{array}$

$\begin{array}{ll}\text { 4.1.4. Other nuclear proteins } & 271\end{array}$

$\begin{array}{ll}\text { 4.1.4.1. Myc } & 271\end{array}$

$\begin{array}{ll}\text { 4.1.4.2. Serum-response factor (SRF) } & 272\end{array}$

$\begin{array}{ll}\text { 4.2. Potential cytokines } & 272\end{array}$

$\begin{array}{ll}\text { 4.3. Integral membrane proteins } & 273\end{array}$

$\begin{array}{ll}\text { 4.3.1. Mouse tissue factor (mTF) } & 273\end{array}$

$\begin{array}{ll}\text { 4.3.2. Glucose transporter } & 273\end{array}$

$\begin{array}{ll}\text { 4.4. Cytoskeletal and extracellular matrix proteins } & 274\end{array}$

$\begin{array}{ll}\text { 4.5. Other immediate early proteins } & 274\end{array}$

$\begin{array}{ll}\text { 5. Delayed early genes and proteins } & 274\end{array}$

$\begin{array}{ll}\text { 5.1. Biosynthetic enzymes } & 275\end{array}$

$\begin{array}{ll}\text { 5.1.1. Ornithine decarboxylase } & 275\end{array}$

$\begin{array}{ll}\text { 5.1.2. Asparagine synthetase } & 275\end{array}$

$\begin{array}{lll}\text { 5.2. Secreted proteins } & 276\end{array}$

$\begin{array}{ll}\text { 5.2.1. Proliferin (MRP) } & 276\end{array}$

$\begin{array}{ll}\text { 5.2.2. Cathepsin L (MEP) } & 276\end{array}$

$\begin{array}{ll}\text { 5.2.3. TIMP (16C8; phorbin) } & 276\end{array}$

$\begin{array}{ll}\text { 5.2.4. Osteopontin } & 277\end{array}$

$\begin{array}{ll}\text { 5.2.5. Stromelysin (transin) } & 277\end{array}$

$\begin{array}{ll}\text { 5.3. Proteins with oncogenic potential } & 278\end{array}$

$\begin{array}{ll}\text { 5.3.1. p53 } & 278 \\ & 278\end{array}$

$\begin{array}{ll}\text { 5.3.2. Ras } & 278\end{array}$

$\begin{array}{ll}\text { 5.3.3. Myb } & 279\end{array}$

$\begin{array}{ll}\text { 5.4. Other proteins } & 279\end{array}$

6. Relationship of immediate early genes identified in fibroblasts to genes induced by other extracellular signalling agents 
1. Introduction

2. Origins $r 296$

2.1. fos $\quad 296$

$\begin{array}{lr}\text { 2.2. jun } & 297\end{array}$

$\begin{array}{lr}\text { 3. Cellular immediate-early genes } & 298\end{array}$

$\begin{array}{lr}\text { 3.1. fos and jun gene families } & 298\end{array}$

3.2. Dimerization and DNA binding $\quad 299$

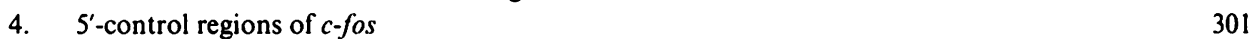

$\begin{array}{lr}\text { 4.1. Serum response element (SRE) } & 301\end{array}$

4.2. SIFRE $\quad 303$

4.3. CRE/CaRE $\quad 303$

4.4. Repression of $c$-fos transcription $\quad 304$

$\begin{array}{lr}\text { Acknowledgements } & 305\end{array}$

$\begin{array}{lr}\text { References } & 305\end{array}$

Chapter 15. Regulation of transcription by insulin, by D.K. Granner and R.M. O'Brien

$\begin{array}{ll}\text { 1. Introduction } & 309\end{array}$

2. Insulin can regulate gene expression at several steps 311

$\begin{array}{ll}\text { 3. Positive effects of insulin on gene transcription } & 312\end{array}$

3.1. Glyceraldehyde-3-phosphate dehydrogenase (GAPDH) 312

$\begin{array}{ll}\text { 3.2. c-fos } & 313\end{array}$

$\begin{array}{ll}\text { 3.3. Glucokinase } & 314\end{array}$

$\begin{array}{lr}\text { 3.4. Gene } 33 & 314\end{array}$

$\begin{array}{lr}\text { 3.5. Prolactin } & 315\end{array}$

$\begin{array}{ll}\text { 3.6. Fatty acid synthase } & 316\end{array}$

3.7. Lipoprotein lipase 316

3.8. Glucose transporter 316

$\begin{array}{ll}\text { 3.9. } \alpha \text {-Amylase } & 317\end{array}$

4. Negative effects of insulin on gene transcription 318

$\begin{array}{ll}\text { 4.1. Phosphoenolpyruvate carboxykinase } & 318\end{array}$

4.2. Growth hormone $\quad 320$

4.3. Insulin receptor 321

5. Other genes 322

5.1. Albumin 322

5.2. Glutamine synthetase $\quad 322$

5.3. Adipsin and glycerol-3-phosphate dehydrogenase 322 
5.4. Tyrosine aminotransferase $\quad 323$

$\begin{array}{lr}\text { 5.5. Miscellaneous effects } & 323\end{array}$

6. Permissive effects of insulin on gene transcription $\quad 324$

$\begin{array}{lr}\text { 6.1. Pyruvate kinase } & 324\end{array}$

$\begin{array}{lr}\text { 6.2. Casein } & 324\end{array}$

$\begin{array}{lr}\text { 6.3. Ovalbumin } & 325\end{array}$

7. Criteria used to establish that insulin per se affects gene transcription 325

$\begin{array}{lr}\text { 8. Conclusion } & 327\end{array}$

$\begin{array}{lr}\text { Acknowledgements } & 328\end{array}$

$\begin{array}{lr}\text { References } & 328\end{array}$

Chapter 16. Regulation of transcription by transforming growth factor- $\beta$, by D.R. Edwards and J.K. Heath

1. Introduction

2. Transduction of TGF $\beta$ signals

3. An overview of the effects of TGF $\beta$ on gene expression 335

3.1. Connective tissue formation and wound-healing responses 335

$\begin{array}{ll}\text { 3.2. Mechanistic considerations } & 339\end{array}$

4. Mechanisms of transcriptional effects $\quad 340$

4.1. Role of nuclear factor I $\quad 340$

4.2. Regulation through fos-binding sequences $\quad 342$

5. Conclusions and future directions 343

Acknowledgements $\quad 344$

References $\quad 344$

Chapter 17. Transcriptional regulation of interferon-inducible genes, by G.C. Sen

$\begin{array}{lr}\text { 1. The interferon system } & 349\end{array}$

2. Interferons and their genes $\quad 350$

$\begin{array}{lr}\text { 3. Induction of IFN synthesis } & 350\end{array}$

4. Interferon actions $r 352$

5. IFN-inducible proteins and genes $\quad 353$

$\begin{array}{lr}\text { 6. IFN-receptors } & 354\end{array}$

$\begin{array}{lr}\text { 7. Signal transduction } & 357\end{array}$

$\begin{array}{ll}\text { 8. Regulation of IFN-inducible gene expression } & 358\end{array}$

9. Cis-acting sequences $\quad 360$

$\begin{array}{lr}\text { 10. Trans-acting factors } & 361\end{array}$

11. Analysis of IFN action in variant cell lines $\quad 364$

12. Mechanism of induction of the IFN genes 365

$\begin{array}{ll}\text { 13. Synergism among inducers } & 36 \%\end{array}$

14. Double-stranded RNA and the interferon system 368

15. Future perspectives $\quad 370$ 
xxii

Acknowledgements

$\begin{array}{ll}\text { References } & 371\end{array}$

Section V. Regulation of transcription by environmental stress 375

Chapter 18. Transcriptional regulation of heat shock genes, by R.E. Kingston 377

$\begin{array}{lr}\text { 1. Introduction } & 377\end{array}$

$\begin{array}{ll}\text { 2. Mutational analysis of heat shock promoters } & 378\end{array}$

$\begin{array}{lr}2.1 . & 379\end{array}$

2.2. Complexity and location of the HSE 381

$\begin{array}{ll}\text { 2.3. The TATA element } & 382\end{array}$

2.4. Elements involved in basal regulation of HSP promoters 383

3. Detection and properties of heat shock factor 386

3.1. Inducible or constitutive binding by HSF 386

$\begin{array}{ll}\text { 3.2. Activation of HSF } & 387\end{array}$

3.3. Other modifications of HSF following heat shock 388

3.4. Binding of HSF to DNA $\quad 390$

$\begin{array}{ll}\text { 4. Mechanism of transcriptional activation by HSF } & 391\end{array}$

4.1. Does HSF function alone? 392

5. Cloning of HSF $\quad 393$

6. Establishment of heat shock genes in chromatin 394

7. Perspectives $\quad 396$

$\begin{array}{lr}\text { Acknowledgements } & 397\end{array}$

$\begin{array}{lr}\text { References } & 397\end{array}$

Chapter 19. Transcriptional regulation of immunoglobulin gene expression, by T.A. Libermann and D. Baltimore

1. Introduction

2. Regulatory elements of immunoglobulin genes $\quad 400$

$\begin{array}{lr}\text { 2.1. The promoter } & 401\end{array}$

2.2. The enhancer $\quad 403$

2.2.1. Immunoglobulin heavy chain enhancer 404

2.2.1.1. The octamer element $\quad 404$

2.2.1.2. The $\mu \mathrm{B}$ element $\quad 406$

2.2.1.3. The $\pi$ element $\quad 408$

2.2.1.4. The E box elements $\quad 409$

$\begin{array}{ll}\text { 2.2.1.5. Other enhancer elements } & 409\end{array}$

2.2.2. Immunoglobulin light chain enhancers $\quad 410$

$\begin{array}{ll}\text { 2.2.2.1. The intronic enhancer } & 410\end{array}$

2.2.2.2. The $3^{\prime}$ enhancer $\quad 412$ 
3. DNA-binding proteins 413

3.1. Octamer-binding factors 413

3.2. E box-binding proteins $\quad 415$

References

Chapter 20. The physiology of the NF- $\kappa B$ transcription factor, by P.A. Baeuerle and D. Baltimore

1. Introduction

2. $\kappa \mathrm{B}$ sequence motifs as inducible transcriptional enhancers $\quad 423$

3. Characteristics of the NF- $\kappa$ B transcription factor 425

3.1. Post-translational activation of NF- $\kappa$ B $\quad 425$

3.2. In vitro activation of NF- $\kappa \mathrm{B}$

3.3. The role of $I \kappa B \quad 426$

3.4. The purified NF- $\kappa$ B protein $\quad 427$

4. Factors related to NF- $\kappa$ B

4.1. H2TF1/KBF1 $\quad 428$

4.2. HIVEN86 $\quad 429$

$\begin{array}{ll}\text { 4.3. EBP-1 } & 430\end{array}$

4.4. An LPS-inducible protein $\quad 430$

4.5. A putative cytokine factor $\quad 430$

4.6. Other ' $\kappa$ B-like factors'

$\begin{array}{ll}\text { 5. Activators of NF- } \kappa \text { B } & 431\end{array}$

5.1. Activators of protein kinases $\quad 431$

5.2. Inhibitors of protein synthesis $\quad 432$

5.3. Double-stranded RNA 432

5.4. Lectins $\quad 433$

5.5. DNA damage 433

$\begin{array}{lr}\text { 5.6. Cytokines } & 433 \\ & \end{array}$

5.7. Viral transactivators $\quad 434$

5.8. The parasite Theileria parva 435

6. Genes activated by the NF- $\kappa$ B transcription factor 436

6.1. The $\kappa$ immunoglobulin light chain 436

6.2. Cytokines 436

6.3. Cell surface receptors 438

6.4. Major histocompatibility antigens and associated proteins 439

$\begin{array}{ll}\text { 6.5. Acute phase proteins } & 440\end{array}$

6.6. Viruses 440

7. Concluding remarks 441

7.1. How can a ubiquitous transcription factor activate genes in a tissue-specific fashion? 441

7.2. NF- $\kappa$ B as a mediator of immune response, inflammatory and distress signals 442

References $\quad 444$ 
xxiv

Chapter 21. Transcriptional control of Drosophila embryogenesis, by M. Levine and J.L. Manley

1. Introduction

2. The initiation of gene expression along the dorsal-ventral axis

3. Localized expression along the anterior-posterior axis

4. Regulation of gene activity in cultured cells

5. Transcriptional activities of homeobox proteins

462

References

Chapter 22. The regulation of transcription during mouse embryogenesis, by P.W.J. Rigby

1. Introduction

2. Mouse development

3. The analysis of transcription during pre-implantation development

4. The exploitation of viruses for the study of transcriptional regulation in embryonal carcinoma cells

4.1. Papovaviruses

4.2. C-type retroviruses

4.3. Adenoviruses

5. Homeobox proteins

6. Regulation of known transcription factors during development

6.1. Octamer-binding proteins

6.2. Other POU homeobox proteins

7. Regulation of RNA polymerase III transcription during development 484

$\begin{array}{ll}\text { 8. Future perspectives } & 485\end{array}$

$\begin{array}{ll}\text { Acknowledgements } & 486\end{array}$

$\begin{array}{ll}\text { References } & 486\end{array}$ 


\title{
Hormonal and liver-specific control of expression of the tyrosine aminotransferase gene
}

\author{
Doris Nitsch, Siegfried Ruppert, Gavin Kelsey, Andreas Schedl, Falk Weih, \\ A. Francis Stewart, Uwe Strähle, Wolfgang Schmid, Carol de Vack, \\ ANDreas Reik, Michael Boshart and GÜNTHER Schütz
}

1. The tyrosine aminotransferase gene as a model system to study the interplay of controlling genes and hormone-signalling pathways

From a single cell a variety of cell types and tissues with differential structures and functions develop. To understand the underlying processes of differentiation it is necessary to elucidate the mechanisms of selective activation of those genes that give cells their characteristic structures and functions. Of particular importance for differentiation processes is the establishment of patterns of gene activity by regulatory genes. As a model system we have chosen the tyrosine aminotransferase (TAT) gene [1] and analysed the regulatory processes which determine its cell- and developmental-specific expression. We are characterizing the control sequences that determine cell-specific expression and the proteins that interact with these regulatory elements in order to understand their mode of action. TAT gene expression is an attractive system with which to analyse the molecular mechanism of a developmental process for the reasons summarized and shown in Fig. 1:

(1) Expression of the TAT gene is cell type-specific. As far as is known, only the parenchymal cells of the liver are able to synthesize the enzyme [1].

(2) Expression of the gene is regulated developmentally: the enzyme is not expressed before birth. Enzyme synthesis starts around birth and attains its maximal level within a few hours [2]. This developmental activation is likely to be dependent on glucocorticoids and glucagon, the effect of which is mediated by cAMP [3].

(3) A particularly interesting aspect of this system is the fact that the activity of the gene is influenced by two genetically defined trans-acting loci as deduced from analysis of a set of mouse mutations and by analysis of expression in somatic cell hybrids. 


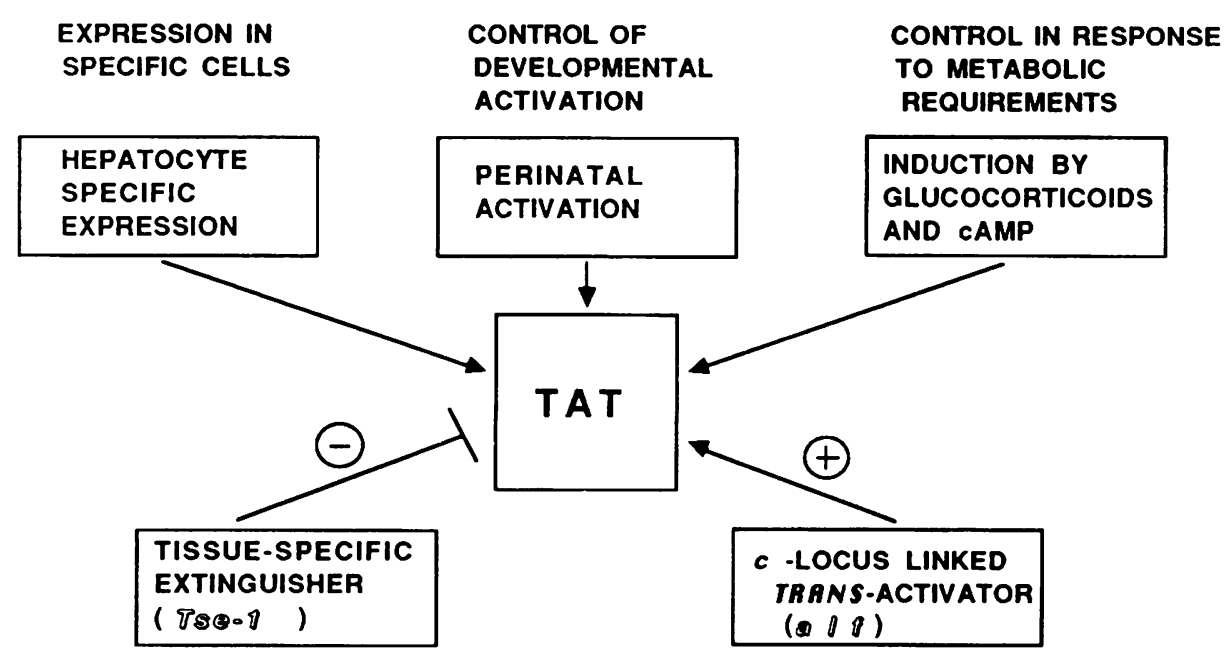

Fig. 1. Control of expression of the tyrosine aminotransferase gene.

(a) The albino lethal mutations of mice are characterized by a set of overlapping deletions within the region of the albino locus (c-locus) on chromosome 7 [4]. It has been shown that several liver-specific enzymes are expressed at a strongly reduced level in homozygous mutant animals [4]. One of the genes affected by the mutation is the TAT gene. The transcription rate of the TAT gene is severely reduced [5], suggesting that the factor indicated by the mutation is involved in cell-specific expression of the gene [6]. Since the structural gene for TAT is not deleted and has been mapped to chromosome 8 [7], it has been concluded that the albino lethal deletions remove a regulatory locus [6], which we denote as alf (factor indicated by the albino lethal mutations).

(b) The second trans-acting factor involved in TAT gene regulation is indicated by the phenomenon of extinction $[8,9]$. In intertypic hybrids of TAT-expressing hepatoma cells and -non-expressing fibroblasts, TAT gene expression is shut off - a phenomenon termed 'extinction'. The work of Keith Fournier and his colleagues [9, 10] has shown that distinct loci are responsible for the extinction of specific gene expression. For extinction of TAT gene expression a locus named 'Tse-I' (tissue-specific extinguisher 1) which maps on mouse chromosome 11 is operative as a dominant negative regulator [9]. Since the TAT gene is encoded on chromosome 8 [7], this clearly indicates that the extinguishing factor also acts in trans.

In order to understand these complex regulatory processes involved in TAT gene regulation and the interplay between controlling genes and signalling molecules, we are characterizing in detail those elements that are important for cell-specific expression as well as for responsiveness towards glucocorticoids and cAMP [11-13]. We are particularly interested in determining the targets for the factors indicated by the 
albino lethal mutations and the tissue-specific extinguisher Tse-1 and the mode of action of these two trans-acting factors. By gene transfer into hepatoma cells, by characterization of proteins interacting with regulatory sequences of the gene using in vivo and in vitro footprinting methods and finally by isolation and characterization of these proteins, we are dissecting the mechanisms underlying the cell- and developmental-specific expression of the TAT gene.

\section{Two distinct trans-acting loci control overlapping sets of liver-specific genes}

Mice homozygous for deletions around the albino locus on chromosome 8 fail to activate expression of a set of neonatal liver functions and die a few hours after birth. The perinatal lethal phenotype is associated with the reduction in activity of a number of enzymes expressed in liver (glucose-6-phosphatase, tyrosine aminotransferase, serine dehydratase and phosphoenolpyruvate carboxykinase), as well as with ultrastructural abnormalities of hepatocytes and cells of the proximal convoluted tubules of the kidney $[4,14]$. However, a large number of other enzymes remain uninfluenced by the mutation, attesting to its specific nature [4]. In the case of phosphoenolpyruvate carboxykinase and TAT, it has been established that the decreased enzyme activities result from lower levels of steady-state mRNA [7, 15], which are due to a decreased transcriptional rate as deduced from nuclear run-on assays [5].

In order to understand the perinatal lethal phenotype more fully and to elucidate the nature and function of the product of the perinatal survival locus, we have attempted to identify additional genes influenced by the albino lethal mutations. Using differential cDNA screening we have collected and characterized genes whose cell type-specific transcription is affected in the mutants [5]. With this approach nine distinct genes could be identified, designated ' $\mathrm{X} 1$ to $\mathrm{X} 9$ ', none of which maps to the locus indicated by the albino lethal deletions [5]. This permits the conclusion that none encodes the transactivating protein indicated by the mutant phenotype. Some of the gene products encoded by these mRNAs have been identified by sequence analysis (see legend to Fig. 2). 15 genes, so far, have been identified whose expression is affected by alf (Fig. 2). Most of the genes are expressed in liver only. Some (X5, ASS and ASL), however, are expressed in all tissues analysed (liver, kidney, brain, heart, lung and skin), but the effect of the deletion is apparent only in liver. Interestingly, the mRNA for C/EBP, a transactivator with restricted tissue distribution [16], is also influenced by alf and is reduced in liver, but not in other tissues.

All the genes found to be affected by the albino lethal mutation are induced by cAMP and glucocorticoids, C/EBP being the only exception [5]. However, expression of the genes encoding proteins involved in mediation of hormonal signalling (the glucocorticoid receptor, the cAMP response element-binding protein (CREB) or protein kinase $\mathrm{A}$ ) is not affected by the mutation [5]. 


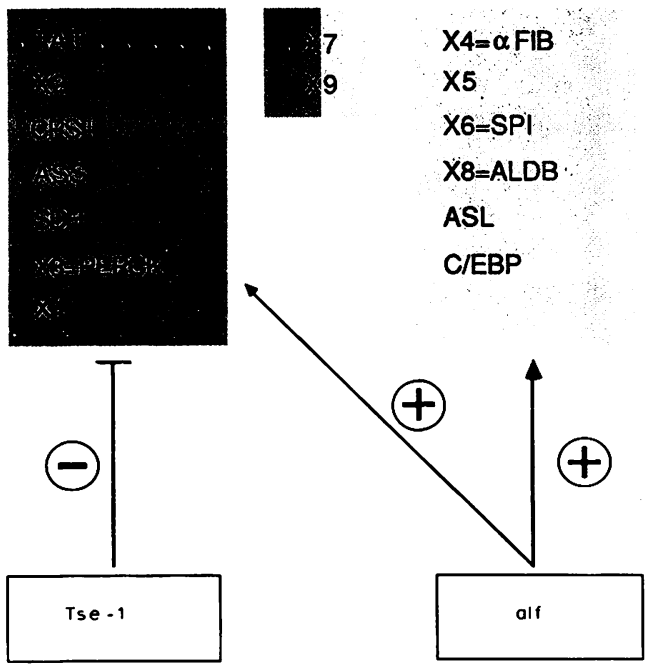

Fig. 2. Co-ordinate regulation of overlapping sets of genes by two distinct transacting loci. All the genes listed are regulated by the factor indicated by the albino lethal mutation (denoted alf). A subset of these genes is also regulated by the tissue-specific extinguisher 1 (Tse- $I$ ). Since the genes coding for X7 and X9 are not expressed in the hepatoma cell lines analysed, evidence for co-regulation by $T$ se- $l$ cannot be established. X1-X9 designate the mouse cDNA clones isolated by subtractive cDNA hybridization. The following abbreviations are used: TAT (tyrosine aminotransferase), CPSI (carbamoylphosphate synthetase I), ASS (argininosuccinate-synthetase), SDH (serine dehydratase), PEPCK (phosphoenolpyruvate carboxykinase), $\alpha$ FIB ( $\alpha$-chain of fibrinogen), SPI (serine protease inhibitor), ALDB (aldolase B), ASL (argininosuccinate-lyase), C/EBP (CCAAT box/enhancer-binding protein).

Interestingly, a subset of the genes affected by the mutation is negatively controlled by the tissue-specific extinguisher locus $T s e-1[5,10]$. As discussed in more detail below, $T$ se-1-dependent extinction can be relieved by cAMP and a $T$ se-1-responsive element co-resides with a cAMP response element (CRE) [12, 17]. This raises the interesting possibility that a functional antagonism between negative control mediated by $T s e-1$ and hormonal induction might play a role in the hormone-dependent perinatal activation of this set of liver genes [2].

In summary, these results show that two trans-acting factors regulate expression of overlapping sets of liver-specific genes. These sets of genes are also characterized by the observations that most of them are activated shortly after birth and that their transcription rates are influenced by both glucocorticoids and cAMP. Since the ultimate demonstration of the function of the gene indicated by the albino lethal mutation depends upon its isolation, we are now attempting to clone it from the knowledge of its chromosomal location [18]. 


\section{Alterations in chromatin structure indicate cis-acting regulatory sequences of the TAT gene}

To understand the various levels of control of the TAT gene it is imperative to identify the regulatory regions of the gene. We have used DNaseI hypersensitive site analysis as a means to identify cis-regulatory elements in the TAT upstream region. By comparing the DNaseI-hypersensitive regions found in expressing and non-expressing cells with the enhancing activity of the sequences comprising the hypersensitive regions in gene transfer assays into these cells, we could establish that specific chromatin changes relate to the function of these sequences $[11,19,20]$. This correlative analysis of hypersensitive sites (HS) and transcriptional enhancers of the TAT gene was performed in hepatoma cells expressing the TAT gene $\left(T s e-I^{-}\right)$, in hepatoma cells carrying a short segment of a human fibroblast chromosome with an active Tse- 1 locus which have a strongly reduced TAT mRNA level [10] and in fibroblasts in which the gene is inactive (Fig. 3).

DNaseI-hypersensitive sites 3.6 and $11 \mathrm{~kb}$ upstream of the initiation site indicate liver-specific enhancers, they are absent in fibroblasts [19]. Both sites are fully developed in $\mathrm{Tse}_{-1} \mathrm{I}^{-}$and $T \mathrm{se}-\mathrm{I}^{+}$hepatoma cells. However, the enhancer at $-3.6 \mathrm{~kb}$ is inactive in cells expressing Tse-1 [12,19]. As will be discussed below, the target for $T$ se- 1 action is the cAMP response element, which is crucial to enhancer function but which by itself does not constitute enhancing activity. Obliteration of its functional activity by $T s e-1$ thus does not lead to disappearance of the HS, in agreement with the complex structure of this enhancer with binding sites for several proteins [12]. The activity of the enhancer at $-11 \mathrm{~kb}$ is not affected by $T s e-1$ [19]. This site is hypersensitive in foetal livers several days before the TAT gene is transcriptionally activated (F. Stewart and G. Yeoh, unpubl. data). This element might function during development to establish an active TAT locus, similar to the role of the dominant control region of the $\beta$-globin gene cluster [21].

\begin{tabular}{|c|c|c|c|c|c|c|c|c|}
\hline \multirow[b]{2}{*}{ cell line } & \multicolumn{2}{|c|}{-11} & \multicolumn{2}{|c|}{-3.6} & \multicolumn{2}{|c|}{$\begin{array}{l}-2.5 \\
\text { inducible }\end{array}$} & \multirow{2}{*}{$\begin{array}{l}\mathbf{P} \\
\mathrm{HS}\end{array}$} & \multirow[t]{2}{*}{$\begin{array}{c}\text { basal } \\
\text { TAT mRNA } \\
\text { level }\end{array}$} \\
\hline & activity & HS & activity & HS & activity & HS & & \\
\hline HEPATOMA (Tse-1 -) & + & present & + & present & + & present & present & high \\
\hline HEPATOMA $\left(T s e-1^{+}\right)$ & + & present & - & present & + & present & $\begin{array}{c}\text { present, } \\
\text { but modified }\end{array}$ & very low \\
\hline FIBROBLAST & - & absent & - & absent & + & absent & absent & $\begin{array}{c}\text { un. } \\
\text { detectable }\end{array}$ \\
\hline
\end{tabular}

Fig. 3. Correlation of DNasel-hypersensitive sites (HS) and enhancer function of the tyrosine aminotransferase gene. The enhancer activities were analysed by transient transfection assays in different cell lines as indicated on the left. Sequences at -11 and $-3.6 \mathrm{~kb}$ act as liver cell-specific enhancers, the element at $-2.5 \mathrm{~kb}$ as a glucocorticoid-inducible enhancer. $P$ denotes the promoter. 
The glucocorticoid-inducible enhancer [11] is characterized by a hormone-dependent $\mathrm{HS}$ at $-2.5 \mathrm{~kb}$. This site is rapidly induced following glucorticoid administration $[11,20]$ and maintained as long as the inducer is present. Removal of glucocorticoids leads to rapid disappearance of the site. The HS is not inducible in fibroblasts, but the enhancer is active in a transfected reporter plasmid [11], indicating additional controls in the endogenous gene.

The HS at -3.6 and $-2.5 \mathrm{~kb}$ have been analysed in detail. As discussed below, this analysis reveals the complex nature of far upstream enhancers and gives an insight into the molecular interactions occurring between constitutive and inducible factors.

\section{The glucocorticoid enhancer of the TAT gene}

Our understanding of how steroid hormones affect gene expression has advanced considerably in recent years [22-24]. Our interest focused on the identification and characterization of elements required for steroid-dependent transcription of the TAT

A

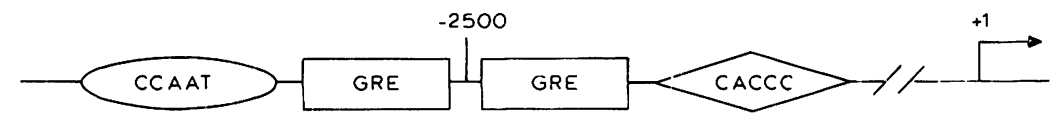

$B$

\begin{tabular}{|c|c|c|}
\hline & INDUCIBILITY & RECEPTOR BINDING \\
\hline GRE - & - & + \\
\hline -GRE-GRE- & ++ & ++++ \\
\hline CACCC GRE & ++ & + \\
\hline -CCAAT GRE- & ++ & n. d. \\
\hline
\end{tabular}

Fig. 4. The glucocorticoid-dependent enhancer of the tyrosine aminotransferase gene has a modular structure. The glucocorticoid-dependent enhancer of the TAT gene (schematically outlined in A) is located 2500 bp upstream of the start site of transcription and is composed of two GREs and sites for transcription factors recognizing the CCAAT and CACCC sequence. (B) A single GRE is not sufficient for induction from a distance. Multiple GREs or a combination of a GRE with binding sites for factors recognizing the CCAAT and CACCC elements are required to constitute a hormone-inducible enhancer. The receptor binds in a co-operative fashion to a GRE dimer when compared to a monomer (indicated by +++++ ). Binding affinity to a GRE is not influenced by the presence of a CACCC element. 
gene [11]. By gene transfer experiments, genomic footprinting analyses and in vitro binding studies with the purified glucocorticoid receptor we characterized glucocorticoid-responsive elements of the TAT gene and defined the role of the hormone in the interaction of the receptor with its recognition sequence.

The element of the TAT gene required for glucocorticoid induction is located 2.5 $\mathrm{kb}$ upstream of the start site of transcription (Figs. 3, 4). These sequences contain two glucocorticoid receptor-binding sites which affect expression of the gene in a synergistic fashion [11] and CCAAT and CACCC box-related sequences (Fig. 4) [25]. Although the proximal receptor-binding site has no inherent capacity to stimulate transcription, when present in conjunction with the distal glucocorticoid response element (GRE), this element enhances glucocorticoid induction of gene expression synergistically [11]. Using the genomic footprinting technique we were able to show that the receptor binds to its target sequence only after induction with hormone. Concomitant with alterations in DNA-protein interaction in vivo at the GRE changes are seen at a CACCC box-related sequence in the vicinity of the GRE [26].

The observation that the GREs are found in close vicinity to binding sites for other transcription factors prompted a more detailed analysis of the dependence of receptor function on other transcription factors [25,27]. It became clear that a single GRE is not capable of mediating hormone inducibility when positioned far upstream of the start site of transcription. Inducibility can, however, be attained by multimerizing the steroid-responsive sequences (Fig. 4), as found in the glucocorticoid-dependent enhancer of the TAT gene [25, 27]. Alternatively, a single steroid-responsive element can function in combination with a binding site for other transcription factors. We have demonstrated that the transcription factors interacting with the CCAAT and CACCC boxes which are found in the vicinity of the TAT GREs, as well as NF1and Spl-binding sites, can fulfil this synergistic action [25, 27]. Interestingly, these combinations of a GRE with different transcription factor-binding sites show strong cell type-dependent induction of expression. For example, the combination of a GRE with a CACCC box is most active in hepatoma cells. This correlates well with the observation that concomitant with receptor binding at the GRE in vivo, alterations in protein-DNA interaction occur at the CACCC box [26].

What is the molecular basis for the functional synergy of glucocorticoid-responsive sequences in vivo? By detailed analysis in vitro of receptor binding to one or two receptor-binding sites using various techniques, we demonstrated that the functional synergy of GREs is based on co-operative binding of the receptor to these elements (Fig. 4). Measurement of the relative affinity showed a $>10$-fold higher affinity of the glucocorticoid receptor to a duplicated GRE when compared to a single element. Thus, co-operative binding of the receptor to two adjacent GREs is a basis for the synergism observed at the level of transcription [28]. However, no evidence for cooperative binding of the receptor and NF1 or the CACCC box-recognizing protein has been found in similar analyses (C. de Vack, unpubl. data).

The DNA elements of the TAT gene which mediate induction by glucocorticoids 
are also capable of mediating response to progesterone and testosterone when transfected in appropriate reporter constructs into cells that contain the corresponding hormone receptors $[27,29]$. This finding is surprising since these hormones control vastly different processes in different target cells. In view of the fact that the receptors mediating the effects of glucocorticoids, progesterone, testosterone and aldosterone interact with the same sequence it was of interest to determine whether the presence or absence of a steroid receptor is sufficient to control the transcriptional activity of genes that harbour a steroid response element. To address this question we introduced an expression vector for the progesterone receptor into hepatoma cells in which this receptor is not synthesized. By stably expressing the progesterone receptor in hepatoma cells we could demonstrate that the TAT gene becomes responsive to progesterone [30]. Thus, we conclude that steroid-specific effects, at least in part, are determined by differential expression of the respective receptors in target tissues. This is at least one mechanism by which steroid-specific gene activation is achieved.

Mutational analysis of response elements has also shown that the sequences required for estradiol- and ecdysone-dependent expression are closely related to those required for glucocorticoid/progesterone induction (Fig. 5) [27, 29, 31]. The similarity of the steroid response elements has its counterpart in the similarity of amino acid residues in the DNA-binding region of the corresponding receptor molecules [22-24]. In line with this close relationship of response elements is the recent demonstration that three amino acid substitutions in the estradiol receptor are sufficient to alter its target specificity to that of the glucocorticoid receptor [32].

\section{Cell-specific expression of the TAT gene}

\subsection{The - 3.6 enhancer is composed of a cAMP-responsive sequence and a liver cell- specific element}

As summarized above we have identified two elements which are important for liver cell-specific expression of the TAT gene located at -3.6 and $-11 \mathrm{~kb}$. This conclusion is based on gene transfer experiments into hepatoma and non-hepatoma cell lines [19]. To characterize the enhancer at $-3.6 \mathrm{~kb}$ in more detail a series of $5^{\prime}$ and $3^{\prime}$ internal deletion mutants was analysed which defined a sequence of $80 \mathrm{bp}$ as absolutely essential for enhancer function of the element located $3.6 \mathrm{~kb}$ upstream [12]. To define the regulatory sequences a series of clustered point mutations was established. Analysis of these mutants showed that mutations in two regions destroyed enhancer function entirely [12]. Each of the two sequences was inactive by itself in front of a heterologous promoter. However, if multimerized, each element could function as a strong transcriptional activator (Fig. 6). One of these elements has a sequence similar to the cAMP response element (CRE) found in cAMP-inducible genes [33, 34]. This element confers strong cAMP induction and interacts in vivo 


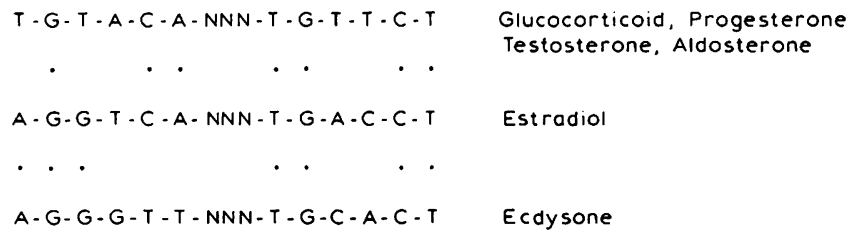

Fig. 5. Sequence comparison of steroid response elements. The response elements for glucocorticoids, progesterone, testosterone and aldosterone are $15 \mathrm{bp}$ palindromic sequences which mediate induction of gene transcription by the respective steroid. The response elements for estrogens and ecdysone are distinct, but closely related sequences. Identical bases in steroid response elements are indicated by dots.

with a protein in expressing hepatoma cells, but not in fibroblasts, as evidenced from genomic footprinting experiments [13]. The intensity of interaction seen at the CRE increases upon cAMP administration. This increase in footprinting activity is transient and is also inducible in the presence of cycloheximide [13]. These observations allow the conclusion that cAMP-dependent post-translational modifications lead to an increased binding activity of a protein, possibly CREB, to the TAT CRE.

A

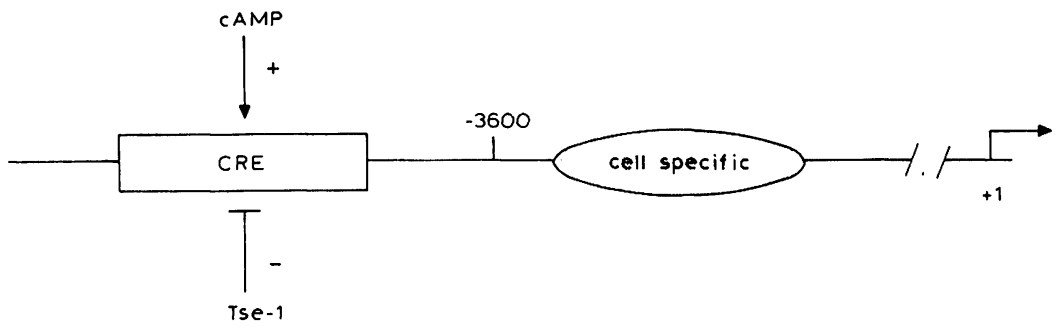

B

\begin{tabular}{|c|c|c|c|c|c|}
\hline & \multicolumn{5}{|c|}{ ENHANCER ACTIVITY IN } \\
\hline & \multicolumn{2}{|c|}{$\begin{array}{l}\text { HEPATOMA } \\
\text { TSE-1- }\end{array}$} & \multicolumn{2}{|c|}{$\begin{array}{l}\text { HEPATOMA } \\
\text { TSE - } 1 .\end{array}$} & \multirow[t]{2}{*}{ FIBROBLAST } \\
\hline & - CAMP & - CAMP & - CAMP & - CAMP & \\
\hline C CRE & - & - & - & - & - \\
\hline CRE CRE & + & +++ & - & +++ & - \\
\hline & - & - & - & - & - \\
\hline & +++ & +++ & +++ & +++ & - \\
\hline CRE & ++ & +++ & - & +++ & - \\
\hline
\end{tabular}

Fig. 6. Two distinct elements are essential for the function of the TAT enhancer at $-3.6 \mathrm{~kb}$. Two essential elements were defined by functional analysis of a series of clustered point mutants: a cell-specific module and a cAMP response element which is the target for Tse-l (A). Enhancer activity of plasmids carrying these elements alone or in combination was determined in transfection assays into hepatoma cells (Tse- $1^{-}$ and $T s e-I^{+}$) and into fibroblasts (B). The two elements are functionally interdependent. Relief of extinction by cAMP demonstrates the dominant effect of cAMP over Tse-1. 
The multimer of the second essential element behaves as a cell type-specific activator of transcription [12]. This element is active in liver cells, but inactive in any other cell type tested so far. In conjunction with the element carrying the CRE sequence, an enhancing element with all the regulatory properties of the TAT gene enhancer can be regenerated (Fig. 6) [12].

\subsection{Reversal of extinction by $c A M P$}

The cAMP response element of the $-3.6 \mathrm{~kb}$ enhancer is also a target for negative regulation by $T_{s e-1}$ [12] (Fig. 6). In a hepatoma microcell hybrid line which contains only a small segment of the human fibroblast chromosome carrying $T s e-1$ [10] administration of CAMP is able to overcome extinction of expression of the transfected reporter gene, thus revealing a functional antagonism between $T s e-1$ and the cAMP signal transduction pathway. In vivo footprinting revealed characteristic changes in DMS reactivity at the CRE. In the presence of a functional Tse- $l$ locus, proteinDNA interaction at the CRE sequence is abolished. This binding can be recovered by addition of cAMP [12]. Thus, the extinguished state of the TAT gene is characterized by the absence of binding at the CRE. As might be expected from the relief of extinction by cAMP, this footprint reappears after administration of the inducer.

As hormones acting via the cAMP pathway are thought to be critically involved in turning on TAT gene expression around birth, this suggests that the functional antagonism between $T s e-1$ and the cAMP pathway might form the basis of a molecular switch governing the onset of TAT gene expression at birth. The strong increase of gluconeogenic hormones around birth may trigger the expression of the TAT gene $[1,2]$. This is in line with previous experience that TAT enzyme activity can be prematurely induced before birth by administration of glucagon in utero [2].

In order to understand the mechanism involved in the cell-specific expression of the TAT gene, and in particular to understand the mode of action of the product of the $T s e-1$ locus, we are presently isolating and characterizing the proteins involved in recognition of the CRE sequence and the liver cell-specific element. Analysis of possible modifications of the CRE-binding protein in response to cAMP and the tissue-specific extinguisher might give an understanding of the biochemical basis of activation of these controlling proteins.

\section{Summary}

Two different signal transduction pathways control the activity of the TAT gene via two inducible enhancers (Fig. 7). These enhancers are composed of constitutive and inducible elements which appear to be crucial for cell-specific and hormone-dependent transcription. The effect of glucagon via the cAMP transduction pathway most likely involves specific phosphorylation events [35]. As shown from genomic foot- 


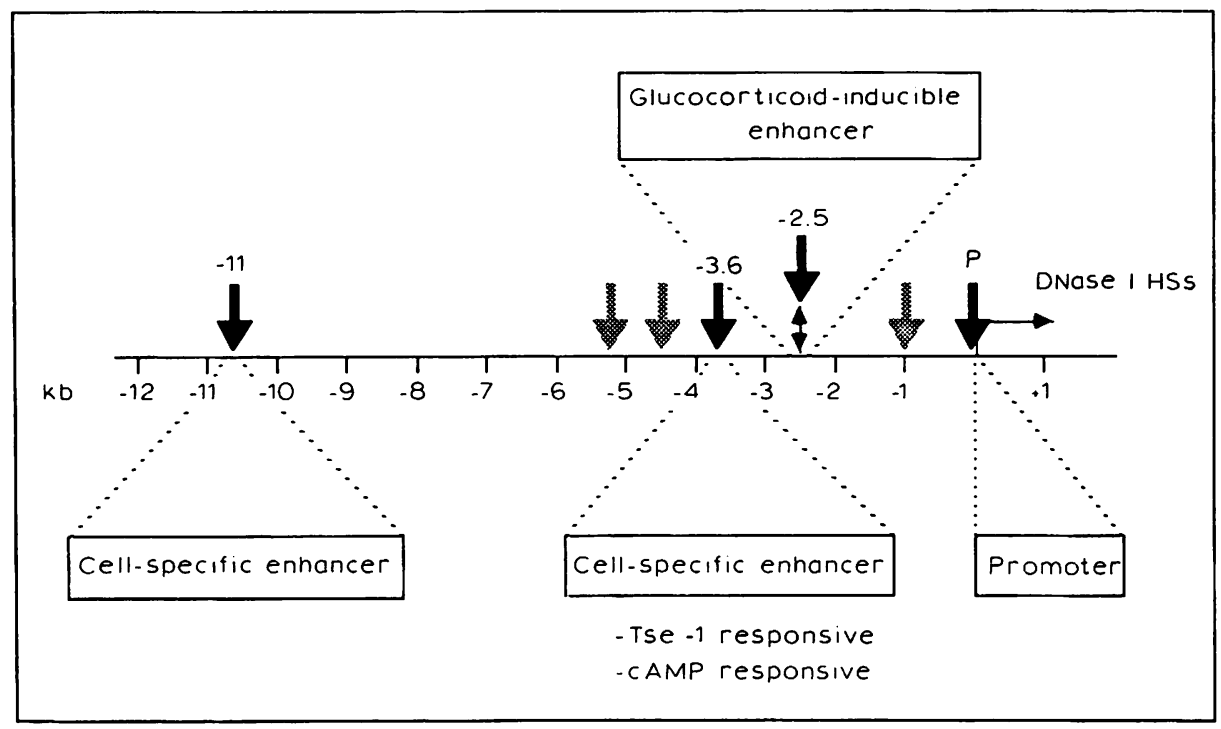

Fig. 7. Several enhancers determine the cell-specific and hormone-dependent activation of the TAT gene. The 5 -flanking region of the TAT gene is outlined with DNasel-hypersensitive regions and enhancers indicated. Shaded and filled arrows point to DNaseI-hypersensitive sites observed in TAT gene-expressing hepatoma lines. The filled arrows indicate functionally identified elements; $P$ indicates the promoter. The dependence of the DNaseI HS at the GRE on glucocorticoids is indicated by the double arrow.

printing experiments this phosphorylation may be the basis of the increased affinity of a DNA-binding protein recognizing the CRE. This CRE is essential for function of the liver-specific enhancer at $-3.6 \mathrm{~kb}$ in hepatoma cells and it has to co-operate with a protein recognizing a liver cell-specific module. Since the cAMP response element is a target for the tissue-specific extinguisher it may contribute, in conjunction with a cell-specific enhancer, to the cell-specific and developmentally timed expression of the gene. The enhancer at $-3.6 \mathrm{~kb}$ is characterized by a constitutive chromatin-hypersensitive site, possibly due to the fact that not only the CRE-binding protein determines the active state of this enhancer. The enhancer at $-11 \mathrm{~kb}$ is not influenced in its activity by cAMP and glucocorticoids but is liver cell-specific. A DNasel-hypersensitive region is present in fetal livers, possibly indicating that this distal element may function early in development to establish an activated locus.

The glucocorticoid-dependent enhancer is characterized by a hormone-dependent DNasel-hypersensitive site which is induced by interaction of the glucocorticoid receptor with its binding site (Fig. 7). The glucocorticoid-dependent enhancer is characterized by the presence of two receptor-binding sites plus binding sites for additional transcription factors recognizing the CCAAT and the CACCC motif. This combination of glucocorticoid receptor recognition sequences with transcription factor binding sites might be involved in the cell-specific modulation of activity of the TAT gene. It is most remarkable that the sequences involved in hormonal control 
function in conjunction with elements which display preferential activity in liver cells. This unique combination may be crucial for the precisely timed onset of expression of the TAT gene at birth in the parenchymal cells of the liver.

\section{References}

1. Granner, D.K. and Beale, E.G. (1985) In: Biochemical Actions of Hormones, Vol. XII, (Litwack, G., ed.), pp. 89-138, Academic Press, New York.

2. Greengard, O. (1970) In: Mechanisms of Hormone Action, Vol. I (Litwack, G., ed.) pp. 53-85, Academic Press, New York.

3. Ruiz-Bravo, N. and Ernest, M.J. (1982) Proc. Natl. Acad. Sci. USA 79, 365-368.

4. Gluecksohn-Waelsch, S. (1979) Cell 16, 225-237.

5. Ruppert, S., Boshart, M., Bosch, F.X., Schmid, W., Fournier, R.E.K. and Schütz, G. (1990), Cell 61, 895-904.

6. Gluecksohn-Waelsch, S. (1987) Trends Genet. 3, 123-127.

7. Schmid, W., Müller, G., Schütz, G. and Gluecksohn-Waelsch, S. (1985) Proc. Natl. Acad. Sci. USA $82,2866-2869$.

8. Schneider, J.A. and Weiss, M.C. (1971) Proc. Natl. Acad. Sci. USA 68, 127-131.

9. Killary, A.M. and Fournier, R.E.K. (1984) Cell 38, 523-534.

10. Lem, J., Chin, A.C., Thayer, M.J., Leach, R.J. and Fournier, R.E.K. (1988) Proc. Natl. Acad. Sci. USA 85, 7302-7306.

11. Jantzen, H.M., Strähle, U., Gloss, B., Stewart, F., Schmid, W., Boshart, M., Miksicek, R. and Schütz, G. (1987) Cell 49, 29-38.

12. Boshart, M., Weih, F., Schmidt, A. and Schütz, G. (1990), Cell 61, 905-916.

13. Weih, F., Stewart, F., Boshart, M., Nitsch, D. and Schütz, G. (1990), Genes Devel. 4, 1437-1449.

14. Trigg, M.J. and Gluecksohn-Waelsch, S. (1973) J. Cell Biol. 58, 549-563.

15. Loose, D.S., Shaw, P.A., Krauter, K.S., Robinson, C., Englard, S., Hanson, R.W. and GluecksohnWaelsch, S. (1986) Proc. Natl. Acad. Sci. USA, 83, 5184-5188.

16. Friedman, A.D., Landschulz, H.W. and McKnight, S.L. (1989) Genes Dev. 3, 1314-1322.

17. Thayer, M.J. and Fournier, R.E.K. (1989) Mol. Cell. Biol. 9, 2837-2846.

18. Kelsey, G.D., Ruppert, S., Boshart, M., Schedl, A., Schmid, W. and Schütz, G. (1989) In: Vectors as Tools for the Study of Normal and Abnormal Growth and Differentiation, NATO ASI Ser., Vol. H34, pp. 47-62, Springer-Verlag.

19. Nitsch, D., Stewart, A.F., Boshart, M., Mestril, R., Weih, F. and Schütz, G. (1990), Mol. Cell Biol. $10,3334-3342$.

20. Becker, P.B., Renkawitz, R. and Schütz, G. (1984) EMBO J. 3, $2015-2020$.

21. Grosveld, F., van Assendelft, G.B., Greaves, D.R. and Kollias, G. (1987) Cell 51, 975-985.

22. Evans, R. (1988) Science 240, 889-895.

23. Green, S. and Chambon, P. (1988) Trends Genet. 4, 309-314.

24. Beato, M. (1989) Cell 56, 332-344.

25. Strähle, U., Schmid, W. and Schütz, G. (1988) EMBO J. 7, 3389-3395.

26. Becker, P.B., Gloss, B., Schmid, W., Strähle, U. and Schütz, G. (1986) Nature 324, 686-688.

27. Strähle, U., Münsterberg, A., Mestril, R., Klock, G., Ankenbauer, W., Schmid, W. and Schütz, G. (1988) Cold Spring Harbor Symp. Quant. Biol. 53, 835-841.

28. Schmid, W., Strähle, U., Schütz, G., Schmitt, J. and Stunnenberg, H. (1989) EMBO J. 8, 2257-2263.

29. Strähle, U., Klock, G. and Schütz, G. (1987) Proc. Natl. Acad. Sci. USA 84, 7871-7875.

30. Strähle, U., Boshart, M., Klock, G., Stewart, F. and Schütz, G. (1989) Nature 339, 629-632.

31. Klock, G., Strähle, U. and Schütz, G. (1987) Nature 329, 734-736.

32. Mader, S., Kumar, U., de Verneuil, H. and Chambon, P. (1989) Nature 338, 271-274.

33. Karin, M. (1989) TIG 5, 65-67.

34. Roesler, W.J., Vandenbark, G.R. and Hanson, R.W. (1988) J Biol. Chem. 263, 9063-9066.

35. Gonzalez, G.A. and Montminy, M.R. (1989) Cell 59, 675-680. 